\title{
Evaluation of Short-term Postoperative Complications According to the Clavien-Dindo Classification System in Thermocautery-assisted Circumcision Cases
}

\section{Termokoter Yardımlı Sünnet OIgularında Kısa Süreli Postoperatif Komplikasyonların Clavien- Dindo Sınıflandırma Sistemine Göre Değerlendirilmesi}

\author{
(D) Mahmut Taha Ölçücü1,2, (D) Kerem Teke2,3 \\ 1 University of Health Sciences Turkiye, Antalya Training and Research Hospital, Clinic of Urology, Antalya, Turkiye \\ ${ }^{2}$ Ağrı State Hospital, Clinic of Urology, Ağrı, Turkiye \\ ${ }^{3}$ Kocaeli University Faculty of Medicine, Department of Urology, Kocaeli, Turkiye
}

\section{What's known on the subject? and What does the study add?}

Our retrospective study demonstrated that thermocautery-assisted circumcision has a short operative time. In addition, adapted shortterm complications to Clavien-Dindo classification system indicate that is tolerable and easily overcome following this surgical technique. Therefore, thermocautery-assisted circumcision may become a practical and fast method for circumcision in areas where circumcision is a common procedure.

\begin{abstract}
Objective: Circumcision is one of the most performed surgical procedures in the world. This study is a retrospective study on the short-term postoperative complications after a thermocautery-assisted circumcision on a series of patients according to the Clavien-Dindo classification system (CDCS).

Materials and Methods: A total of 2.356 male thermocautery-assisted circumcision cases, performed by two urologists in a hospital, were examined retrospectively. The mean age, type of anesthesia, peri- and postoperative complications, durations of the procedures, mean number of sutures, cohesive bandage requirements, and mean recovery times were evaluated.

Results: The age of the patients ranged from 1 to 32 years with the mean age being 8.33 years. While 1.943 patients ( $82.47 \%)$ were only locally anesthetized, the remaining $413(17.53 \%)$ were sedated in addition to local anesthesia. The mean values of the operative time, suture count, total

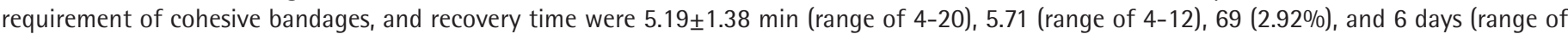
4-25), respectively. The short-term postoperative complications of 1.573 patients who returned to the hospital for a physical examination after being discharged were edema (mild, moderate, and severe), bleeding (simple and hematoma-causing), and infection (mild, moderate, and serious). The postoperative complications were adapted to the CDCS as grade 1 (638 patients, 40.55\%), grade 2 (12 patients, $0.76 \%)$, grade $3(6$ patients, $0.38 \%)$, grade 4 (0 patients, $0 \%)$, and grade 5 ( 0 patients, $0 \%)$. There was no statistically significant difference between the patients in terms of complications adapted to the CDCS who received local anesthesia and those who received sedation + local anesthesia ( $p>0.05)$. Additionally, there was no significant difference in the development of penile edema between the patients who were sutured with Vicryl Rapide and normal Vicryl ( $p>0.05)$.
\end{abstract}

Conclusion: Our retrospective results indicate that thermocautery-assisted circumcision has a short operative time and is tolerable despite its shortterm complications. Thermocautery-assisted circumcision may be a useful method in regions where circumcision is common.

Keywords: Circumcision, Clavien-Dindo classification system, Complications, Edema, Thermocautery

Öz

Amaç: Sünnet, dünyada en çok yapılan cerrahi işlemlerden biridir. Bu çalışma, Clavien-Dindo sınıflandırma sistemine (CDSS) göre bir hasta serisinde termokoter yardımlı sünnet sonrası kısa dönem postoperatif komplikasyonlar üzerine yapılan retrospektif bir çalışmadır.

Correspondence: Mahmut Taha Ölçücü MD, Antalya Training and Research Hospital, Clinic of Urology, Antalya, Turkiye E-mail: matah_ol@hotmail.com ORCID-ID: orcid.org/0000-0002-4721-2807

Received: 31.12 .2019

Accepted: 12.02 .2020

Cite this article as: Ölçücü MT, Teke K. Evaluation of Short-term Postoperative Complications According to the Clavien-Dindo Classification System in Thermocautery-assisted Circumcision Cases. J Urol Surg 2020;7(3):218-226.

- Copyright 2020 by the Association of Urological Surgery / Journal of Urological Surgery published by Galenos Publishing House. 
Gereç ve Yöntem: Bir hastanede iki ürolog tarafından gerçekleştirilen toplamda 2,356 erkek termokoter yardımlı sünnet olguları retrospektif olarak incelendi. Ortalama yaş, anestezi tipi, peri ve postoperatif komplikasyonlar, işlem süreleri, ortalama sütur sayısı, yapışkanlı bandaj gereksinimi ve ortalama iyileşme süreleri değerlendirildi.

Bulgular: Hastaların yaşı 1 ile 32 yıl arasında olup, ortalama yaş 8,33 yıl idi. 1,943 hastaya $(\% 82,47)$ sadece lokal anestezi uygulanırken, kalan 413 $(\% 17,53)$ hasta lokal anesteziye ek olarak sedatize de edildi. Ameliyat süresi, sütur sayısı, yapışkanlı bandajların toplam gereksinimi ve iyileşme süresinin ortalama değerleri sırasıyla; 5,19 1,38 dk (4-20 dk.), 5,71 (4-12.), 69 (\%2,92) ve 6 gün (4-25 gün). Taburcu edildikten sonra fizik muayene için hastaneye başvuran 1,573 hastanın kısa dönem postoperatif komplikasyonları; ödem (hafif, orta ve şiddetli), kanama (basit ve hematom nedenli) ve enfeksiyon (hafif, orta ve ciddi) idi. Postoperatif komplikasyonlar CDSS'ye göre; derece 1 (638 hasta,\%40,55), derece $2(12$ hasta, $\% 0,76)$, derece 3 (6 hasta, \%0,38), derece $4(0$ hasta, \%) ve derece $5(0$ hasta, \%) olarak görüldü. Lokal anestezi alan hastalar ile sedasyon + lokal anestezi alan hastalar arasında CDSS'ye göre komplikasyonlar açısından istatistiksel olarak anlamlı fark yoktu $(p>0,05)$. Ek olarak rapid vikril ile normal vikril ile sütürüze edilen hastalar arasında penil ödem gelişimi açısından anlamlı bir fark yoktu $(p>0,05)$.

Sonuç: Retrospektif sonuçlarımız, termokoter yardımlı sünnetin kısa bir ameliyat süresine sahip olduğunu ve kısa dönem komplikasyonlarına rağmen tolere edilebilir olduğunu göstermektedir. Termokoter yardımlı sünnet, sünnetin yaygın gerçekleştirildiği bölgelerde kullanışlı bir yöntem olabilir.

Anahtar Kelimeler: Sünnet, Clavien-Dindo sınıflama sistemi, Komplikasyonlar, Ödem, Termokoter

\section{Introduction}

Circumcision is a surgical procedure mostly performed for religious and medical reasons. It involves the excision of the foreskin that covers the distal end of the male penis (1) and is one of the most frequent surgical interventions in the world (2). Although circumcision is not accepted by many people worldwide, there are several health benefits of it, such as reduction in the risk of acquiring HIV, urinary tract infections, herpes simplex, balanitis, phimosis, and penile cancer and a reduction in the risk of causing bacterial vaginosis in female partners and transmitting human papilloma virus and syphilis $(3,4)$.

However, with all the aforementioned benefits circumcision can have, it is still a surgical procedure and bears a few potential complications. Therefore, this procedure must be done under sterile and safe conditions as with any surgical acts. Many different techniques (such as Gomco clamp, PlastiBell, Mogen clamp, and dorsal slit) are used for performing circumcision $(5,6)$, however, thermocautery-assisted circumcision is a technique that has become popular in recent years (6-8), especially in Turkey, where a circumcision center has been using the thermocautery-assisted shield technique for over 30 years. Over 80,000 circumcisions have been performed without any complication related to the thermocautery device (8).

Further, the standardization of complications allows the comparison of surgical experiences with other studies. Hence, the modified Clavien-Dindo classification system (CDCS) is one of the most popular categorization systems for complications $(9,10)$.

In this study, we aimed to evaluate the short-term complication rates of thermocautery-assisted circumcision cases in a single institution of the eastern region of Turkiye. Then, we standardized the postoperative complications according to the CDCS.

\section{Materials and Methods}

Male thermocautery-assisted circumcision cases that were carried out by two urologists (MTÖ and KT) were examined between 1 June 2016 and 15 November 2017 at the Agri State Hospital, Clinic of Urology, Ağrı, Turkiye. A total of 2.679 patients were circumcised during the period. Those who had previous penile surgery or trauma, bleeding disorders, allergic reactions to the anesthetics, systemic diseases, or paraphimosis and patients who were noncompliant were excluded from the study. Patients with phimosis were included in this cohort. The mean age, anesthetic type, number of sutures, operation time, cohesive bandage requirements, recovery time, and complication rates of these cases are indicated in Table 1. The study was performed retrospectively with the approval of the Erzurum Atatürk University Faculty of Medicine, Clinical Research Ethics Committee (approval number: B.30.2.ATA.0.01.00/127). All patients gave informed consent prior to being admitted to the study.

\section{Surgical Preparation}

Dorsal penile nerve blockade was performed with lidocaine $\mathrm{HCl} 20 \mathrm{mg} / \mathrm{mL}$ ampoule (Jetokain Simplex, Adeka, Turkiye) 2-4 $\mathrm{mL}$ for patients who received only local anesthesia. Ketamine $\mathrm{HCl}$ vial (Ketalar, Pfizer, USA) in $4.5 \mathrm{mg} / \mathrm{kg}$ or midazolam ampoule 0.1-0.5 mg/kg (Dormicum, Roche, Switzerland) were applied intravenously, then local anesthesia was performed on sedo-analgesia-receiving patients. Sedo-analgesia doses were increased or decreased during sedation by an anesthesiologist.

\section{Surgical Technique (Figures 1. a,b,c,d,e,f)}

The prepicium was removed from the glans penis with the help of a clamp and a sponge, and the remaining smegmas were cleaned again with povidone iodine 10\% solution (Poviiodeks, Kimpa, Turkiye). In a manner similar to the one in the guillotine method, the prepicium was clamped with a flat clamp, described 


\begin{tabular}{|c|c|}
\hline \multicolumn{2}{|l|}{ Before discharge } \\
\hline Total circulation cases $(\mathrm{n})$ & 2.356 \\
\hline Mean age \pm SD (years), (range) & $8.33 \pm 3.46,(1-32)$ \\
\hline $\begin{array}{l}\text { Type of anesthesia } \\
\text { Local }(\%) \\
\text { Sedation + Local }(\%)\end{array}$ & $\begin{array}{l}1.943(82.47 \%) \\
413(17.53 \%)\end{array}$ \\
\hline $\begin{array}{l}\text { Bleeding }(\%) \\
\text { Perioperative }(\%) \\
\text { Postoperative }(\%) \\
\text {-Hematoma }(\%)\end{array}$ & $\begin{array}{l}68(2.88 \%) \\
43(1.82 \%) \\
25(1.06 \%) \\
-4(0.16 \%)\end{array}$ \\
\hline Mean duration of procedure (minute), (range) & $5.19 \pm 1.38,(4-20)$ \\
\hline Mean number of sutures (range) & $5.71 \pm 1.68,(4-12)$ \\
\hline Total usage of cohesive bandage $(\%)$ & $69(2.92 \%)$ \\
\hline \multicolumn{2}{|l|}{ After discharge } \\
\hline $\begin{array}{l}\text { The patients who were controlled after } \\
\text { discharge (n) } \\
\text { The patients who did not visit the hospital for } \\
\text { examination after discharge (n) }\end{array}$ & $\begin{array}{l}1.573(66.76 \%) \\
783(33.23 \%)\end{array}$ \\
\hline $\begin{array}{l}\text { Edema }(\%) \\
\text { Mild edema }(\%) \\
\text { Moderate edema }(\%) \\
\text { Severe edema }(\%)\end{array}$ & $\begin{array}{l}592(37.63 \%) \\
439(27.90 \%) \\
124(7.88 \%) \\
29(1.84 \%)\end{array}$ \\
\hline $\begin{array}{l}\text { Infection }(\%) \\
\text { Mild infection (\%) } \\
\text { Moderate infection (\%) } \\
\text { Serious infection (\%) }\end{array}$ & $\begin{array}{l}39(2.47 \%) \\
25(1.58 \%) \\
9(0.57 \%) \\
5(0.31 \%)\end{array}$ \\
\hline Bleeding & None \\
\hline Mean recovery time \pm SD (day), (range) & $6.00 \pm 1.50,(4-25)$ \\
\hline
\end{tabular}

as "shield technique" earlier (11). A thermocautery tool (Warme Medizinische, Beschneidung Gerat, QX - 2100, Germany) was used to cut the prepuce. The device had seven levels for cutting. Appropriate heat levels were used according to the patient's age and the foreskin thickness. We also had multiple cautery probes. The sterilization of probes was strictly performed using highlevel disinfectants. Bleeding dorsal vein and mucosal vessels were thermocauterized after cutting the prepuce. Thereafter, the remaining excessive tissue of mucosa was excised using a thermocautery tool. Synthetic, absorbable suture materials (3/04/0, Polyglactin 910, Vicryl Rapide ${ }^{\circledR}$, Ethicon, USA or 3/0-4/0, Polyglactin 910, Vicryl, Ethicon, USA) were used for skin closure of the surgical wound by interrupted sutures. Vicryl Rapide was used in patients aged $<10$ years, while other type of Vicryl was used in patients aged $\geq 10$ years. After circumcision, a dressing containing nitrofurazone $2 \%$ cream (Furacin, Zentiva, Turkiye) was applied. Cohesive bandages were used for hemostatic dressing in patients with bleeding. The time from the start of cutting the prepuce to the last suture was recorded as the procedure time (in $\mathrm{min}$ ).

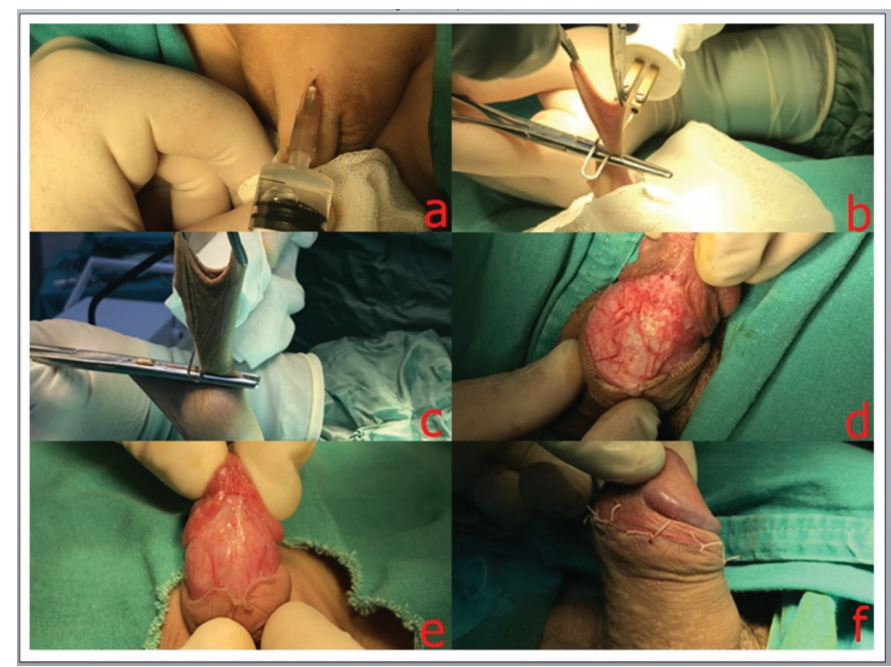

Figure 1. Thermocautery-assisted circumcision steps: (a) Dorsal penile blockage. $(b, c)$ Excision of prepicium with thermocautery device from different patients. $(d, e)$ Imaging of the frenulum from different patients after excision. (f) Imaging of the penis after suturing

\section{Follow-up and Discharge}

The sedo-analgesia-receiving patients were monitored for a minimum of $12 \mathrm{hr}$, and the local-anesthesia-receiving patients were monitored for a minimum of $3 \mathrm{hr}$ in the hospital. Patients with no postoperative problems (bleeding, allergic reactions, etc) in their follow-ups were discharged. As a standard procedure, for patients aged $<15$ years, ibuprofen $20-30 \mathrm{mg} /$ $\mathrm{kg}$ oral suspension (Dolven, Sanofi, France) and for patients aged $>15$ years, diclofenac sodium tablet $50 \mathrm{mg}$ (Dolorex, Abdi Ibrahim, Turkey) $2 \times 1$ by oral route were prescribed, respectively, as an anti-inflammatory. As a standard procedure, it was recommended that the dressings should be removed at the 2448-hr mark by patients or their families after soaking them in warm water for 10 min. Patients were recommended to apply bacitracin $15.000 \mathrm{UI}+$ Neomycin Sulphate $150 \mathrm{mg}$ skin pomade (Thiocilline, Abdi İbrahim, Turkiye) $4 \times 1$, limiting motion, bed rest, wearing a skirt or underpants suitable for circumcision, and refraining from bathing for three days post circumcision. They were also advised to return to the hospital without any delay if bleeding, color change to the glans penis, pain that was nonresponsive to analgesic, edema, leakage from the wound, itching, or rush occurred anywhere in the body. In the absence of any complications, the patients were advised to return to the hospital on the fourth day post circumcision. Furthermore, patients' phone numbers were recorded so that the hospital staff could reach them later when required. The observation of skin integrity between the sutures was defined as the healing wound. The recovery period was determined based on the complete wound healing.

The complications that occurred during and after circumcision (peri- and postoperative) were recorded. The postoperative 
complications were also categorized according to the modified CDCS $(9,10)$ and are presented in Table 2 .

\section{Statistical Analysis}

The mean and range values were calculated using the Statistical Package for the Social Sciences version 22.0. The chi-square test was used for comparing the categorical variables among groups such as anesthesia and the development of edema due to suture type. Spearman's rank test was used to evaluate the correlation between the age and the complications according to the CDCS.

\section{Results}

The patients who had a previous penile surgery or trauma $(n=18)$, bleeding disorders $(n=4)$, allergic reactions to the anesthetics $(n=9)$, systemic diseases $(n=11)$, or paraphimosis $(n=5)$, and patients who were noncompliant $(n=87)$ were excluded from the study. In addition, the data from 189 cases were not noted properly. Thus, a total of 323 cases were excluded from the study. After all exclusions ( $n=323$ ), a total of 2.356 out of the 2,679 cases were found to be appropriate for this study. The mean age of the 2,356 patients was $8.33 \pm 3.46$ (range of 1-32) years. A total of $1,943(82.47 \%)$ patients were given only local anesthesia and 413 (17.53\%) were given both sedation and local anesthesia. The mean number of sutures, operative time, and the total usage of cohesive bandages are summarized in Table 1. A total of $1.573(66.76 \%)$ patients returned to the hospital for a physical examination on the fourth postoperative day and the remaining 783 patients (33.23\%) who failed to visit the hospital were contacted via telephone calls. It was found that the patients who did not return to the hospital did so because they had no complaints. Additionally, of the 1,573 patients who returned (59.88\%), 942 did not present with any postoperative complications in the physical examination (Table 1).

The most common complication registered in this study was postoperative edema. Patients signaled that postoperative edema started two-four days after the patients were discharged.

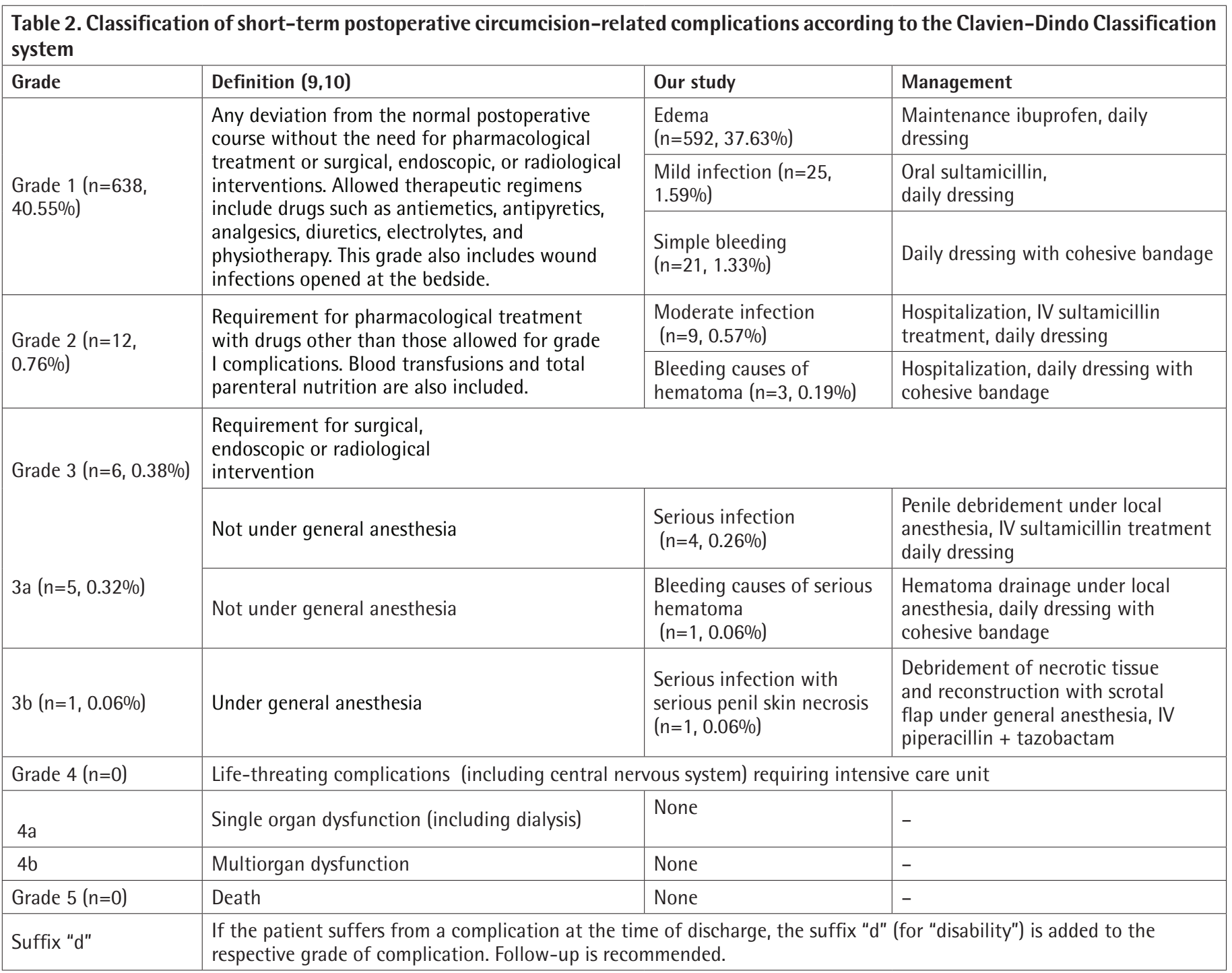


A total of 592 of the 1.573 patients who returned to the hospital presented with edema $(37.63 \%$, CDCS grade 1). The degree of mild, moderate, and severe on the edema scale was determined when the edema was completely resolved. The resolution of edema was observed at 4-7 days, 7-10 days, and 10 or more days in mild (439 patients, 27.90\%), moderate (124 patients, 7.88\%), and severe (29 patients, 1.84\%) edema cases, respectively. The mild or moderate edema cases were easy to overcome and no further complaints were heard from the patients and/or their parents. Maintenance ibuprofen and daily dressing were recommended to patients in these cases, and the edema fully disappeared. However, in the cases of severe edema, it was observed that the patients and/or patients' relatives quite often became agitated. There were no clinical findings other than the appearance of severe edema in such patients. Maintenance ibuprofen and daily dressing with topical hydrocortisone cream (HIPOKORT 0.5\% 30 g, ORVA, İzmir, Turkiye) were recommended. The edema in such patients healed completely (Figure 2). Vicryl Rapide was used in 1.536 patients aged $<10$ years and Vicryl in 820 patients aged $\geq 10$ years. Of those who came to follow-up, Vicryl Rapide was used in 1.024 cases and Vicryl in 549 cases. No significant difference was observed in the development of penile edema between the patients who were sutured with Vicryl Rapide and those sutured with normal Vicryl (381 vs 211, respectively, $p=0.632$ ).

The second most common complication was bleeding, which occurred in $68(2.88 \%)$ patients before discharge. No bleeding was signaled after the discharge. There were $43(1.82 \%)$ and 25 cases (1.06\%) of peri- and postoperative bleeding, respectively. While in the perioperative bleeding cases, the bleeding was stopped via thermocautery and the dressings were then supported by cohesive bandages, in postoperative bleeding cases, the dressings of the patients were changed and supported

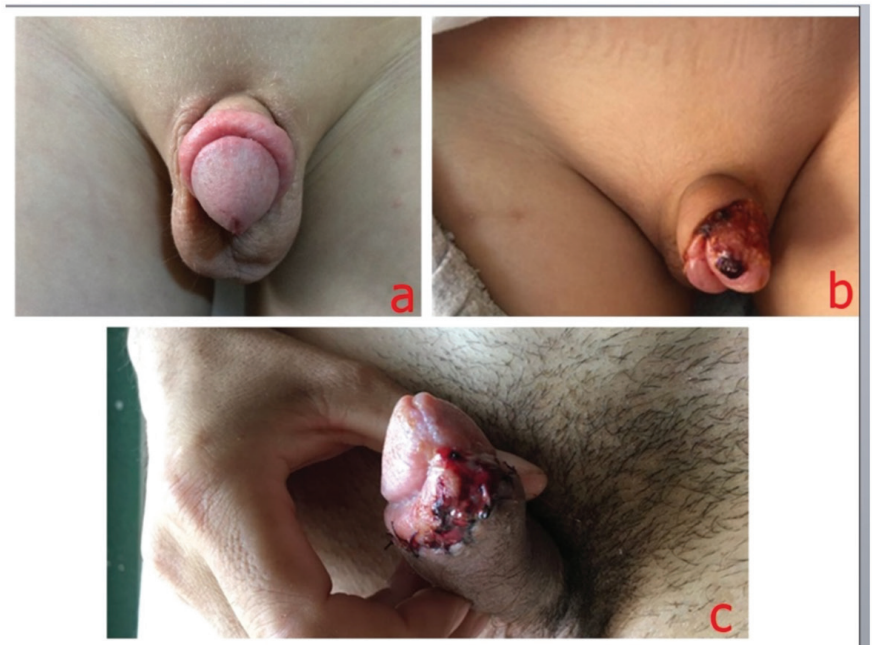

Figure 2. Imaging of short-term complications after circumcision. (a) Moderate edema of subcorona. (b) Serious infection of dorsal part of glans. (c) Serious infection of the frenulum by cohesive bandages, and the patients were followed-up for 12 hr. A total of 21 patients presented with postoperative simple bleeding and were treated with daily cohesive bandage dressings; they were discharged after $12 \mathrm{hr}(0.89 \%$, CDCS grade 1). Furthermore, hematomas developed in four patients $(0.16 \%)$ with postoperative bleeding. Such patients were observed for $48 \mathrm{hr}$ in the hospital and treated with daily cohesive bandages. While the hematomas in three cases regressed and recovered $(0.12 \%$, CDCS grade 2$)$, due to the amount of hematoma in a 10-year-old patient who had continuous leakage from the wound area that did not decrease, the suture of the frenulum was opened (Figure 3. a,b). The bleeding vessels were found and thermocauterized via device, and the wound area was sutured again under local anesthesia (0.04\%, CDCS grade 3a, Figure 3c). Cohesive bandages were used to support the dressing again. The patient was discharged on the third postoperative day without any complications.

The total infection ratio was $39(2.47 \%)$ in the patients who followed-up at the hospital after circumcision. We categorized the cases as mild (a minimal rush and color change to the wound area), moderate [an occasional leakage in the wound area or minimal necrosis $\left(<1 \mathrm{~cm}^{2}\right)$ on the suture line], and serious infections [a continuous leakage or serious necrosis $(>1$ $\mathrm{cm}^{2}$ ) on the suture line or anywhere on the penile skin]. Twentyfive cases of mild infection were treated with oral sultamicillin and daily dressing (1.58\%, CDCS grade 1, Figures 2. a,b,c). Nine patients with moderate infections were treated with daily IV sultamicillin 500 mg (Sulcid, İbrahim Ethem, Ulagay, Turkiye) $4 \times 1$ and bacitracin 15,000 UI + neomycin sulfate $150 \mathrm{mg}$ skin pomade (Thiocilline, Abdi İbrahim, Turkiye) 8x1 daily dressing $(0.57 \%$, CDCS grade 2$)$. Five cases $(0.31 \%)$ had serious infections, four of which were given IV sultamicillin in the hospital. In addition, necrotic tissue debridement and daily dressing were

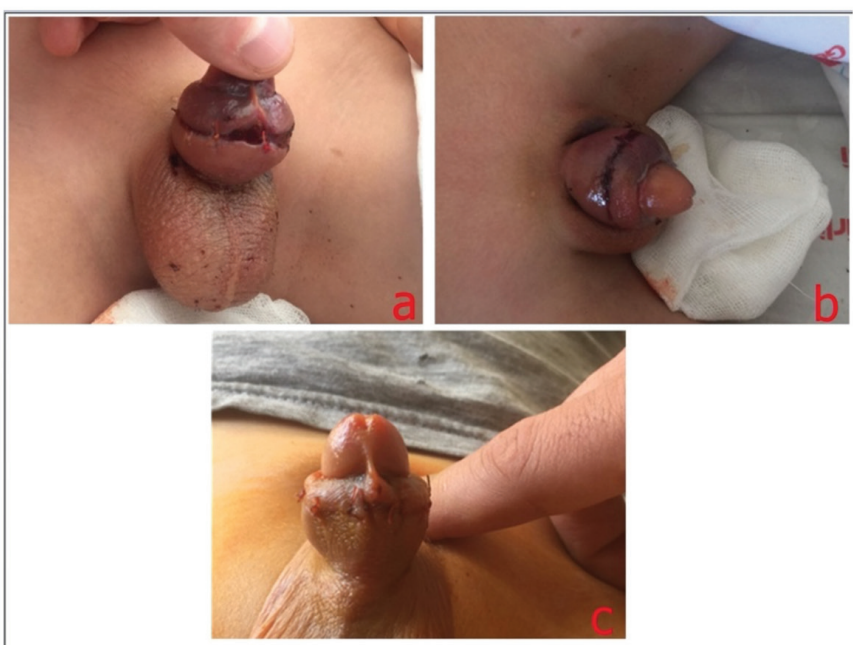

Figure 3. Imaging of hematoma after circumcision. (a) Imaging of ventral penis. (b) Imaging of dorsal penis. (c) Imaging of the penis at the first day after drainage of hematoma 
performed under local anesthesia for these four patients $(0.25 \%$, CDCS grade 3a). All patients with mild and moderate infections recovered. Four patients with serious infections recovered as a result of the treatment. One 19-year-old patient did not respond to the treatment. An approximately $6 \mathrm{~cm}^{2}$ area with necrosis was debrided from the right mid-lateral to the penis root, and it was surrounded with scrotal flap by a plastic surgeon $(0.06 \%$, CDCS grade $3 b$, Figure 4 . a,b,c,d). The patient was treated with IV piperacillin + tazobactam $4.5 \mathrm{~g}$ (Tazocin, Pfizer, USA) 4x1 and $2 \times 1$ cohesive bandage dressing for 10 days before discharge. On the 10th day of the patient's follow-up, the scrotal flap was determined to be successful (Figure 4d). All these complications and data are summarized in Table 1.

As shown in Table 2, all postoperative complications were also adapted according to the CDCS; grade 1 (638 patients, 40.55\%), grade 2 (12 patients, $0.76 \%)$, grade 3 (6 patients, $0.38 \%$ ), grade 4 (0 patients, 0\%), and grade 5 (0 patients, 0\%) $(9,10)$. No statistically significant difference was observed between the patients who received local anesthesia and those that received sedation + local anesthesia ( $>0.05$, Table 3 ). There was no correlation between the age and complications according to the $\operatorname{CDCS}(p=0.858, r=0.005)$. Additionally, the mean recovery period for patients was six (range of 4-25) days (Table 1).

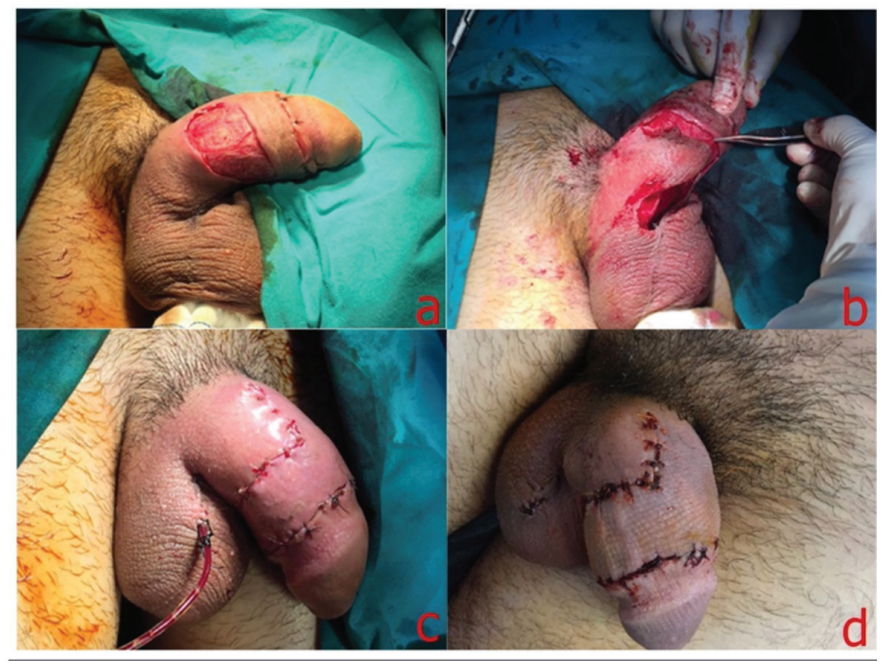

Figure 4. Imaging of debridement and reconstruction of a patient with serious infection accompanied with penile skin necrosis. (a) Imaging of the right part of the penis after debridement. (b) Transfer of scrotal flap to the defective area. (c) Imaging of the penis at the first day after reconstructive surgery. (d) Imaging of the penis at the $10^{\text {th }}$ day after the reconstructive surgery

\section{Discussion}

The thermocautery-assisted shield technique has been proven to be an inexpensive, fast, and practical circumcision method and has therefore become more popular. However, there is a lack of proven results for this method in the literature $(11,12)$.
Table 3. The comparison of standardized complications between groups with different anesthetized approach

\begin{tabular}{|c|c|c|c|}
\hline & $\begin{array}{l}\text { Local } \\
(n=1224)\end{array}$ & $\begin{array}{l}\text { Local + sedation } \\
(n=349)\end{array}$ & p-value \\
\hline Grade $1(n=638)$ & $509^{*}$ & $129^{*}$ & 0.680 \\
\hline Grade $2(n=12)$ & $10^{*}$ & $2^{*}$ & 0.482 \\
\hline $\begin{array}{l}\text { Grade } 3(n=6) \\
3 a(n=5) \\
3 b(n=1)\end{array}$ & $\begin{array}{l}4^{*} \\
1^{*}\end{array}$ & $\begin{array}{l}1^{*} \\
0^{*}\end{array}$ & $\begin{array}{l}0.692 \\
0.778 \\
\end{array}$ \\
\hline Grade $4(n=0)$ & $0^{*}$ & $0^{*}$ & - \\
\hline Grade $5(n=0)$ & $0^{*}$ & $0^{*}$ & - \\
\hline \multicolumn{4}{|c|}{$\begin{array}{l}{ }^{*} \text { Chi-squared test was used for nonparametric tests. There were } \\
\text { no statistically significant differences between groups. } \mathrm{P}<0.05 \\
\text { was considered as statistically significant }\end{array}$} \\
\hline
\end{tabular}

This article provides several statistical results and comparisons within a huge set of patients (a total of 2,356-1,573 examined physically, 783 reached by telephone after discharge) that underwent thermocautery-assisted circumcisions. The shortterm complications were examined within four postoperative days, and the thermocautery-assisted circumcision technique was discussed in light of the current literature.

There are various techniques for circumcision. Other than the sleeve, slit, and guillotine techniques, which are performed with standard surgical equipment, there are Gomco, Mogen, PlastiBell, Tara, and Shang Ring techniques, which use special clamps $(13,14)$. Furthermore, modified techniques have been identified recently (15).

As with every surgical procedure, circumcision comes with some potential complications. Bleeding, wound infection, secondary phimosis, urethral or glandular injuries, and urinary retention can be observed soon after the operation. Long-term complications of the circumcision are excess or inadequate excision of the foreskin, concealed penis, adhesions between penile skin and the glans penis, penile deformations, secondary hypospadias skin bridges, poor wound healing, granu-loma, and psychological disorders, besides frequent, long-term meatal stenosis (16-19).

The most common complications in circumcision using conventional methods are bleeding and infection (20). A Turkish study reported the rates of these complications as 3.1\% and $0.52 \%$, respectively (21). Contrary to the conventional methods, the complications and distribution of complications are somewhat different in the thermocautery-assisted circumcision. For instance, Makhlouf and Kootb (22) pointed out that the most common complications in their series of 518 patients who underwent circumcision with a thermocautery device were reversible edema on the suture line $(2.5 \%)$, infection $(1 \%)$, and bleeding (0\%) (22). Another paper in Egypt similarly reported that there was no bleeding in thermocautery-assisted 
circumcisions in 2,000 children (23). Furthermore, Arslan et al. (24) performed 5,871 thermocautery-assisted circumcisions and applied suture-less bandages in 3,420 patients in Sudan, while 2,451 patients were given sutures and bandages. While bleeding developed in only three patients $(0.05 \%)$ and a scrotal abscess $(0.01 \%)$ was noted, no further complications were determined in that study. As a result of Arslan et al's (24) study, it has been determined that thermocautery-assisted circumcision can be performed safely with appropriate equipment and personnel in regions where circumcisions cannot be performed in hospitals for socioeconomic reasons. According to these studies, the decrease in bleeding and infection rates is remarkable when compared with conventional methods. However, we found that the rates of complications were $2.88 \%$ for perioperative bleeding (after discharge none) and 2.47\% for infection in our study.

Saracoglu et al. (14) in their study compared the conventional and thermocautery techniques. The study consisted of a total of 110 patients, and no bleeding was reported in the thermocautery group. Moreover, Karaman et al. $(11,12)$ have reported that the thermocautery technique is suitable and cost-effective method for patients with bleeding disorders because it reduces the factor replacement. Although, in our study, bleeding and infection rates were slightly higher than the aforementioned studies, these-short term complications were tolerable and easily treated.

In Aykac et al's (6) study, the most common complication of thermocautery-assisted circumcision is edema. While this ratio was $29.6 \%$ in total for transient and prolonged edema, bleeding and infection were not observed in their study (6). In our cohort, the most common complication was mild-degree edema $(27.90 \%)$ on the suture line that disappeared in about four-seven days (37.63\% for all patients). The increased local hypervascular permeability due to heat-induced trauma on the circumcision line may be the possible reason for edema. There is no information about the standardized or optimal heat adjustment to perform thermocautery-assisted circumcision in the literature. Non-standardized and/or non-optimal thermocauterization may possibly lead the edema on the suture line. Further studies are needed to investigate the cause of edema and find the optimal head adjustment to perform thermocautery-assisted circumcision.

Thermocautery device for circumcision is different from electro cautery systems. Tuncer et al. (25) compared the effects of thermocautery, bipolar cautery, monopolar cautery, and the scalpel in rat circumcision model. They reported that (1) thermocautery caused higher collagen proliferation compared with the monopolar device and that (2) thermocautery group had a superior epithelization and injury depth when compared with the bipolar cautery group. Despite these histopathological alterations, the use of thermocautery for circumcision has found to be safe and resulted in better wound healing in rats without any complications (25).

In the current literature, tissue necrosis or ischemia could be observed in some cases of penile blockage with lidocaine plus epinephrine (26), hence we did not use lidocaine plus epinephrine for penile blockage. The necrosis seen in our study was thought to be related to infection.

Recently, a modified CDCS has been used to classify surgical complications. The CDCS has also been accepted for use in postoperative complications (27). Surgery-related complications have been standardized and published according to the CDCS (28-30). Tuncer and Deger (31) in their study reported the CDCSadapted version of circumcision complications and compared their data with a few other published studies. In this research, the perioperative, early- and late-postoperative complications of 1,780 patients who underwent thermocautery-assisted circumcision were presented under the guidelines of the CDCS. For instance, bleeding (four patients), glans-skin bridge (one patient), and secondary phimosis/trapped penis (three patients) in peri- and postoperative patients were determined as grades $3 a, 3 a$, and $3 b$ complications, respectively (31). On the other hand, according to the CDCS, complications that would require additional surgery, such as grade 3 complications, were seen in six patients $(0.035 \%)$ in our study, and grades 4 and 5 complications $(0 \%)$ were not seen at all. Consequently, this CDCS-adapted complication assessment provides convenience and a comparison with the data of other studies.

In pediatric cases, suture-less tissue adhesive techniques have been reported to be safe (32). However, it is known that sutures are much more cost-effective than tissue adhesives. When the number of suture in our study was compared with that of Saracoglu et al.'s (14), they were found to be similar (5.71 vs 6.7, respectively). In conventional methods, cohesive bandages are used in most circumcisions because of the pressure effect to control bleeding. In our study, the bandage requirements were very low, as in Saracoglu et al.'s (14) (2.92\% vs 3.6\%, respectively). While the duration of the conventional circumcision varies from 13.8 to $23.7 \mathrm{~min}$ (33-35), the mean operation time for each of the three studies conducted on thermocautery-assisted circumcision [our study, Saracoglu et al. (14), and Aykac et al. (6)] was approximately $6 \mathrm{~min}$. These results show that thermocautery-assisted circumcision is more advantageous than conventional techniques in terms of procedure time. With conventional techniques, recovery time ranges between 7 and 10 days, while in our study, the mean recovery time was 6 days. In Aykac et al.'s (6) study, this decreased to 4.3 days (6), indicating that thermocautery is successful in terms of the recovery process. 


\section{Study Limitations}

The limitations of this study could be the retrospective design for short-term postoperative complications after circumcision on a series of patients (children and adults) and a lack of longterm analysis in the study.

\section{Conclusion}

Our retrospective study demonstrated that thermocauteryassisted circumcision has a short operative time. Additionally, the adapted short-term complications to CDCS indicate that it is tolerable and can be easily overcome following this surgical technique. Therefore, thermocautery-assisted circumcision may become a practical and fast method for circumcision in regions where circumcision is a common procedure. Furthermore, welldesigned, prospective trials are needed to indicate the shortand long-term complications of this technique in the future.

\section{Ethics}

Ethics Committee Approval: The study was performed retrospectively with the approval of the Erzurum Ataturk University School of Medicine Clinical Research Ethics Committee (approval number: B.30.2.ATA.0.01.00/127).

Informed Consent: All patients gave informed consent prior to being admitted to the study.

Peer-review: Externally peer-review.

\section{Authorship Contributions}

Concept: M.T.O and K.T., Design: M.T.O. and K.T., Data Collection or Processing: M.T.O., Analysis or Interpretation: M.T.O. and K.T., Literature Search: M.T.O. and K.T., Writing: M.T.O. and K.T.

Conflict of Interest: No conflict of interest was declared by the authors.

Financial Disclosure: The authors declared that this study received no financial support.

\section{References}

1. Ince $B$, Dadaci $M$, Altuntas $Z$, Bilgen F. Rarely seen complications of circumcision, and their management. Turk J Urol 2016;42:12-15.

2. Gorgel SN, Erten Tol B. The impact of the application of a penile block before circumcision on the postoperative FLACC score and analgesic requirement. Turk J Urol 2013;39:39-42.

3. Reed JB, Njeuhmeli E, Thomas AG, Bacon MC, Bailey R, Cherutich P, Curran K, Dickson K, Farley T, Hankins C, Hatzold K, Justman J, Mwandi Z, Nkinsi L, Ridzon R, Ryan C, Bock N. Voluntary medical male circumcision: an HIV prevention priority for PEPFAR. J Acquir Immune Defic Syndr 2012;60 Suppl 3:S88-95.

4. Eisenberg ML, Galusha D, Kennedy WA, Cullen MR. The Relationship between Neonatal Circumcision, Urinary Tract Infection, and Health. World J Mens Health 2018;36:176-182.
5. Stang HJ, Snellman LW. Circumcision practice patterns in the United States. Pediatrics 1998;101:E5.

6. Aykac A YO, Ural O, Aygun BA, Baran Ö, Aydin C, Yılanoğlu RO Rapid Way of Circumcision: Bipolar Diathermic Knife. Turkiye Klinikleri J Urology 2015:6:15-19.

7. Tuncer AA, Erten EEA. Examination of short and long term complications of thermocautery, plastic clamping, and surgical circumcision techniques. Pak J Med Sci 2017;33:1418-1423.

8. Ozkan L. Examination of short and long term complications of thermocautery, plastic clamping, and surgical circumcision techniques. Pak J Med Sci 2018:34:776.

9. Dindo D, Demartines N, Clavien PA. Classification of surgical complications: a new proposal with evaluation in a cohort of 6336 patients and results of a survey. Ann Surg 2004;240:205-213.

10. Morgan M, Smith N, Thomas K, Murphy DG. Is Clavien the new standard for reporting urological complications? BJU Int 2009;104:434-436.

11. Karaman MI, Zulfikar B, Caskurlu T, Ergenekon E. Circumcision in hemophilia: a cost-effective method using a novel device. J Pediatr Surg 2004;39:15621564.

12. Karaman MI, Zulfikar B, Ozturk MI, Koca O, Akyuz M, Bezgal F. Circumcision in bleeding disorders: improvement of our cost effective method with diathermic knife. Urol J 2014;11:1406-1410.

13. Abdulwahab-Ahmed A, Mungadi IA. Techniques of male circumcision. J Surg Tech Case Rep 2013;5:1-7.

14. Saracoglu $\mathrm{M} \mathrm{OH}$, Zengin $\mathrm{T}$, Kerman HS. Comparison of thermal cauteryassisted circumcision with the conventional technique. Human Andrology 2014;4:34-37.

15. Mokal N, Chavan N. Modified safe technique for circumcision. Indian J Plast Surg 2008;41:47-50.

16. Ahmed A, Mbibi NH, Dawam D, Kalayi GD. Complications of traditional male circumcision. Ann Trop Paediatr 1999;19:113-117.

17. Weiss HA, Larke N, Halperin D, Schenker I. Complications of circumcision in male neonates, infants and children: a systematic review. BMC Urol 2010;10:2.

18. Naimer S. Circumcision complications. Isr Med Assoc J 2006;8:518-519; author reply 519.

19. Krill AJ, Palmer LS, Palmer JS. Complications of circumcision ScientificWorldJournal 2011;11:2458-2468.

20. Ben Chaim J, Livne PM, Binyamini J, Hardak B, Ben-Meir D, Mor Y Complications of circumcision in Israel: a one year multicenter survey. Isr Med Assoc J 2005;7:368-370.

21. Ozkan A, Ozorak A, Oruc M. Retrospective Investigation of Complications in Nineteen Hundred Cases of Circumcision. Konuralp Tip Dergisi 2012;4:8-12.

22. Makhlouf G, Kootb M. Bone cutting and heat cautery circumcision. The Egyptian Journal of Surgery 2015;34:258-260.

23. Hay SA. The use of thermal cautery for male circumcision. JKAU Med Sci 2009;16:89-93.

24. Arslan D, Kalkan M, Yazgan H, Unuvar U, Sahin C. Collective circumcision performed in Sudan: evaluation in terms of early complications and alternative practice. Urology 2013;81:864-867.

25. Tuncer AA, Bozkurt MF, Bayraktaroglu A, Koca HB, Dogan I, Cetinkursun $\mathrm{S}$, Embleton DB. Examination of histopathological changes of scalpel, monopolar, bipolar, and thermocautery applications in rat experimental circumcision model. Am J Transl Res 2017;9:2306-2313.

26. Gul M, Kaynar M, Sekmenli T, Ciftci I, Goktas S. Epinephrine Injection Associated Scrotal Skin Necrosis. Case Reports in Urology 2015;2015:3.

27. Mitropoulos D, Artibani W, Biyani CS, Bjerggaard Jensen J, Roupret M, Truss M. Validation of the Clavien-Dindo Grading System in Urology by the 
European Association of Urology Guidelines Ad Hoc Panel. Eur Urol Focus 2018;4:608-613.

28. Balci M, Tuncel A, Guzel O, Aslan Y, Keten T, Koseoglu E, Erkan A, Atan A. Evaluation of the complications in transperitoneal laparoscopic renal and adrenal surgery with Clavien-Dindo classification. Turk J Urol 2016;42:7073.

29. Mothes AR, Mothes HK, Radosa MP, Runnebaum IB. Systematic assessment of surgical complications in 438 cases of vaginal native tissue repair for pelvic organ prolapse adopting Clavien-Dindo classification. Arch Gynecol Obstet 2015;291:1297-1301.

30. Yoon PD, Chalasani V, Woo HH. Use of Clavien-Dindo classification in reporting and grading complications after urological surgical procedures: analysis of 2010 to 2012. J Urol 2013;190:1271-1274.
31. Tuncer AA, Deger M. Incidence of Complications Following Thermocauteryassisted Circumcisions. Urol J 2018.

32. Lane V, Vajda P, Subramaniam R. Paediatric sutureless circumcision: a systematic literature review. Pediatr Surg Int 2010;26:141-144.

33. Fraser ID, Goede AC. Sutureless circumcision. BJU Int 2002;90:467-468.

34. Ozkan KU, Gonen M, Sahinkanat T, Resim S, Celik M. Wound approximation with tissue glue in circumcision. Int J Urol 2005;12:374-377.

35. Arunachalam P, King PA, Orford J. A prospective comparison of tissue glue versus sutures for circumcision. Pediatr Surg Int 2003;19:18-19. 